\title{
A Follow-Up Study of the Factors Shaping the Career Choices of Library School Students at the University of Alabama
}

Our paper presents the results of a survey of MLIS students' motivations for choosing a library career, as well as their outlook on the job market, preferences for various subfields, and dreams about the future. In 2004 several researchers conducted a survey of MLIS students at the University of Alabama's School of Library and Information Studies and reported the results in a 2006 RUSQ article. In a field of constant change, it is essential that a new study is conducted to glean current motivations for pursuing a MLIS degree. New technologies, economic issues, and other factors could affect a new generation of librarians' mindsets. Therefore we replicated the earlier survey, added some new questions, and compared our results. This article describes the results of the current survey. It shows that myriad reasons motivate students to pursue the MLIS, and librarians who have an interest in their new colleagues will find this paper of interest. We also suggest some practical steps that reference librarians (as well as human resource officers and library school administrators) can follow to recruit new librarians. This paper is based on a poster presented at the Alabama Library Association conference (ALLA), April 10, 2009, in Auburn, Alabama.
W hy did you choose a career in library and information science? When we posed this question to a group of MLIS students as part of a recent survey, one student replied, "I have a variety of interests and being a librarian entails doing something different every day." Another expressed an "enthusiasm for information organization and sharing," while another said he relished the "service aspects of librarianship." One leaned toward librarianship because she has a "personal disposition for information management." Another soon-to-be librarian gave the classic reply, "I love books!" and others claimed they loved working in the library or just loved libraries in general. These are but a few of the reasons why students decided to enroll in the University of Alabama's (UA) School of Library and Information Studies (SLIS). Indeed many reasons exist as to why individuals choose the LIS field. In this article we present the complete results of a survey about UA SLIS students' motivations for choosing the field as well as their other beliefs and expectations about the profession, and we interpret
Stephanie D. Taylor, R. Alexander Perry, Jessica L. Barton, and Brett Spencer

\section{Stephanie D. Taylor, R. Alexander \\ Perry, and Jessica L. Barton are students enrolled in the master's degree program at the University of Alabama's School of Library and Information Studies in Tuscaloosa, Alabama. Brett Spencer is Reference Librarian, University of Alabama, Tuscaloosa. Submitted for review June 29, 2009; revised and accepted for publication September 29, 2009.}

Reference \& User Services Quarterly, vol. 50, no. 1, pp. 35-47 (c) 2010 American Library Association. All rights reserved.

Permission granted to reproduce for nonprofit, educational use. 
these findings to provide suggestions for recruiting new librarians.

SLIS graduate assistants at UA conducted a career survey of their fellow students in 2004 and, in a 2006 RUSQ article, published the results along with many recruitment ideas. ${ }^{1}$ Five years have passed and significant changes have affected the economy, the nation, and consequently LIS field. One of the most important events is the past year's recession, and this issue clearly must be addressed in relation to potential professionals in LIS careers. Furthermore, the tide of technological change continues unabated, reshaping the landscape of the library field. New subfields have taken form. In addition, more LIS graduate programs offer distance education courses, opening the door for aspiring librarians who might not have had the opportunity to enter the field otherwise. In January 2009, we believed the time had come for a follow-up survey that would find out whether LIS students' motivations and perceptions had changed in response to these developments.

As three SLIS graduate students and a reference librarian, we realized the importance of learning why students choose the field so that the library profession can actively recruit new members. Over the past few years, leaders in the field have also spoken about the need for more recruitment, emphasizing that the quality and quantity of librarians available will help determine the field's success. For instance, one president of the American Library Association (ALA) has called upon librarians to try to recruit two new colleagues each year. ${ }^{2}$ ALA and many of its roundtables and divisions have invested a great deal in developing recruitment tools, and the ALA has even created a "Recruitment Assembly" to coordinate its efforts. ${ }^{3}$ While recruitment is not normally as crucial an issue for LIS as it is for most professions, the coming wave of retirements from the library field has given an extra impetus to ALA's recruitment efforts. According to the Occupational Outlook Handbook, 2008-9 edition, two-thirds of librarians are fortyfive years old or over, a demographic fact that translates into an increasing number of retirements and a resulting 4 percent growth in librarian employment between 2006 and 2016. ${ }^{4}$

On top of this higher rate of attrition, the LIS profession (and reference librarianship in particular) faces an increasingly diverse set of challenges, ranging from the implementation of new information technologies to enhancing information literacy among their patrons. In addition, more and more library jobs are opening up in nontraditional library settings that often require subject expertise. For all these reasons, the LIS field needs to attract highly skilled people with interests, education, and experiences in such areas as technology, teaching, customer service, and specialized fields like medicine and law. The LIS field also needs open-minded people who can adapt to potential rapid changes in the technological and economic environments. And the profession must persevere in its efforts to recruit members who reflect the cultural diversity of the United States.

The long-term trend is toward a continued need to recruit more librarians to both replenish the ranks of retirees and fill new types of library positions. In 2008, Library Journal reported the results from their annual "Placements and Salaries Survey" of LIS graduates and noted that "despite a difficult economy and tightening budgets, both jobs and salaries rose for 2007 grads. . . . All indications from the graduates and the programs responding are that the LIS profession continues to be viable, even healthy, and forward looking." ${ }^{5}$ Furthermore, because of the recession, many libraries across the country are experiencing higher use as patrons seek out free library services, a trend that increases the need for librarians. On this note, after reviewing hundreds of careers to find the best job markets during the recession, U.S. News and World Report listed librarian as one of the thirty best careers of 2009. ${ }^{6}$ Neither has the rise of new technologies negated the role of the librarian; technology has changed librarians' jobs, but not replaced librarians themselves. Indeed, many libraries need professionals who can carry out traditional librarian functions as well as professionals who can work with the new technologies.

Thus, to maintain the LIS field's vitality and libraries' critical mission in American society, reference librarians must help identify and enlist outstanding new professionals who can lead the field into the twenty-first century. Because they work with the public, reference librarians are well positioned to help with recruitment efforts. As many other fields shed jobs during the economic downturn, reference librarians have an excellent opportunity to strengthen their own profession as well as help people who are in the process of changing careers by telling them about the rewards of an LIS career. Leaders within the reference subfield have encouraged reference librarians in their recruitment efforts for the past several years. In particular, Connie Van Fleet and Danny P. Wallace, former editors of RUSQ, have called on the Reference and User Services Association (RUSA) to assist local librarians with recruitment. ${ }^{7}$ 


\section{LITERATURE REVIEW}

The previous RUSQ article reporting the UA SLIS students' career preferences offered an exhaustive review of the literature up to 2004. Since then, there have been no general studies surveying American LIS students to determine their motivations for attending library school or their decision to pursue LIS as a profession. There have, however, been studies that focus on either a specific type of librarianship or on a specific aspect of library career development (such as recruitment or salaries) also covered by our study.

For example, Shannon used focus groups and surveys to discover why individuals chose school librarianship as a path of study and future career. Employability and career flexibility were the primary factors. ${ }^{8}$ In 2006, the first two issues of Science $\&$ Technology Libraries, were dedicated entirely to recruitment. Pellack describes ways to increase the appeal of science librarianship, ${ }^{9}$ while Smith offers strategies that LIS educators can use to recruit science and technology (sci-tech) librarians. Smith recommends increasing access to degree programs via web technologies and fostering partnerships with sci-tech librarians. ${ }^{10}$ Kim and Sin used a Web-based survey to develop better recruitment strategies for students from minority groups. Among their suggested strategies are financial support, work opportunities, recruitment programs with more proactive and tailored advertisements, and personal contact with people from minority groups. ${ }^{11}$ Hines and Baker surveyed 180 business librarians to examine why these librarians chose the profession and to explore their careers prior to entering the library field. The previous careers listed were varied; the top three, however, were library paraprofessionals, administrative assistants, and teachers. The top influencing factor was job function. ${ }^{12}$

Issa and Nwalo surveyed 1,128 Nigerian LIS students and found that only 472 listed LIS as their first choice of study. The report concludes that among the 472, the most common reason for choosing LIS is prior work experience in libraries, and the second most common reason is job security. ${ }^{13}$ Dewey and Keally conducted a case study at the University of Tennessee to develop techniques for recruiting academic librarians with culturally diverse backgrounds. The authors discuss the cultural role academic libraries play in students' lives, thus making diversity an important quality among the library staff that serve the students, and recommend that librarians ally themselves with other national and international organizations when creating recruitment strategies that empha- size cultural diversity. ${ }^{14}$ In addition to these newer studies, Library Journal has continued to conduct its annual placements and salaries survey of library schools and graduates.

Concurrent with this study is the ongoing Workforce Issues in LIS (WILIS) project led by researchers at the School of Information and Library Science and the Institute on Aging at the University of North Carolina-Chapel Hill. Their project, in two phases, investigates some of the issues addressed in our study and it will contribute to the profession's understanding of career and educational factors. ${ }^{15}$

Thus, while several recent studies have focused on specific LIS subfields or occupational issues, none give an overview of the many career influences and motivations of the general LIS student in the United States. This suggests the need for an update to the 2004 UA career survey. Replicating the 2004 study highlights important developments in the field caused by technology's unrelenting growth, job market changes, and economic turbulence. It can also illustrate effective methods of recruitment by giving LIS practitioners a clearer understanding of current LIS students.

\section{METHOD}

We used the 2004 questionnaire again in 2009 with some minor updates, giving it a total of twentyfour items. The 2004 authors had adapted a survey originally developed by library school students at the University of Texas. ${ }^{16}$ The items requested basic demographic information, like age, gender, and semesters completed. It also asked participants what their motivations were for entering LIS programs, career and specialty track preferences, as well as their job outlook, salary expectations, and perceptions of librarianship as a profession.

After reviewing the 2004 questionnaire, we decided to add five items. We asked the participants to rate how important they thought information technologies were in a library on a scale of one to ten and how important they thought it was prior to attending SLIS. Additionally, we asked participants to rate their ability to use information technologies prior to attending SLIS. Because technology has become even more prevalent in the field, the responses to these questions can give more insight as to why individuals choose to become librarians. We also requested information about previous careers and college degrees to gather more background knowledge about library students and recognize any themes in their educational and professional history.

In March 2009, after obtaining institutional review board approval, we distributed the survey to 
onsite and distant-education students in the MLIS program at the UA SLIS. We carried out the onsite survey by requesting permission from several faculty members to give out the survey to willing students in their classes. The 2004 survey had only encompassed onsite students, but we expanded the 2009 study to include the responses of distance students. Some of the distance students completed the surveys at UA's remote site in Gadsden, Alabama, while others submitted responses via e-mail from their home computers. In total, 107 questionnaires were filled out, 39 from distance students and 68 from onsite students. While we cannot generalize to all LIS students using the UA sample, we can contribute to the field's knowledge of LIS students and offer recruitment ideas that are based on empirical data.

\section{DEMOGRAPHICS}

In our sample, we found a heavy representation of females, nearly 72 percent, and most students were in their twenties (52 percent). The second largest age group was thirty to thirty-nine (24 percent). Of the remaining students, 12 percent were in their forties, 10 percent were in their fifties, and less than 1 percent were older than sixty. A majority of the students had completed at least two semesters of the SLIS program (including the current semester), an important fact to note since the process of attending library school may reshape students' beliefs about the field.

LIS students have extremely varied educational backgrounds: 20 percent of our respondents had English degrees, 12 percent had history degrees, 6 percent had education degrees, 5 percent had communications degrees, and 4 percent had psychology degrees. Others included music, political science, sociology, business, art, theatre, philosophy, mineral engineering, classics, computer science, theology, anthropology, economics, marketing, and general studies. Many students held a master's degree or a post-undergraduate degree in other fields, and 2 percent of those surveyed held JDs.

The career backgrounds proved to be just as wide ranging; 23 percent of those surveyed had previously worked in a library, but we also found strong representation from other fields. The second most represented former career was teaching (12 percent). Other students used to work in retail and sales, communications, marketing, food service and restaurant work, technical support, insurance, entertainment, banking, social services, legal administration, editing, healthcare, nonprofit education, accounting, support services, and the computer industry. They worked as lawyers, flight attendants, paralegals, ministers, pianists, babysitters, archaeologists, dorm counselors, artists, aircraft mechanics, museum collection managers, homemakers, technical writers, journalists, data processing assistants, administrative assistants, medical transcriptionists, records specialists, archivists, financial analysts, public services managers, office managers, and software validation engineers.

These findings should come as good news for the library profession because they indicate that a library career has broad appeal and attracts people from general and specialized backgrounds, people-intensive and technology-intensive fields, the private and public sector, and students as well as seasoned professionals. The people flowing into the library field will bring a variety of skills and perspectives with them, and the profession can capitalize on their pool of experiences to meet the diverse information challenges faced by twentyfirst century libraries.

\section{CHOOSING LIS}

For most, the decision to pursue a career in library sciences has remained a postcollege decision. When asked how long a career in library and information studies had been a goal, participants' answers were similar in both the 2004 and 2009 studies. Only 6 percent of the participants wanted a career in librarianship before starting college, while 39 percent considered it a goal since college; 21 percent of participants became interested within five years of graduating college, while 32 percent became interested in librarianship five or more years after graduating college. Perhaps by targeting future recruitment efforts toward high school and undergraduate students, the number of graduating students interested in LIS will rise.

Also comparable to the 2004 study, 42 percent of participants said working in a library prior to entering library school strongly influenced their decision to attend (figure 1). Only 4 percent stated that working in a library had no influence on attending library school. Many factors-experiencing library work first hand, learning about all the possible job functions and specialties that one might not know about otherwise, building momentum from work experience, striving for promotion within the organization, and meeting enthusiastic librarians-likely motivate nonlibrarians working at libraries to enroll in MLIS programs.

\section{INTEREST IN VARIOUS SUBFIELDS}

We asked the LIS students what subfields and types of libraries they preferred, and allowed them 
to check more than one answer (figures 2 and 3). The 2009 respondents had the same top subfield preference as the 2004 respondents: reference. An ALA survey in 1989 also identified reference as the most popular subfield. ${ }^{17}$ The field of reference has changed extensively over the past two decades, but it has continued to be the most preferred specialty, perhaps because it allows for interaction with patrons. Reference may also be most popular with new entries because it is one of the most visible and well-known subfields among the general public.

One major difference between 2009 and 2004 is that more of the 2009 respondents preferred subfields outside of the traditional subfields than

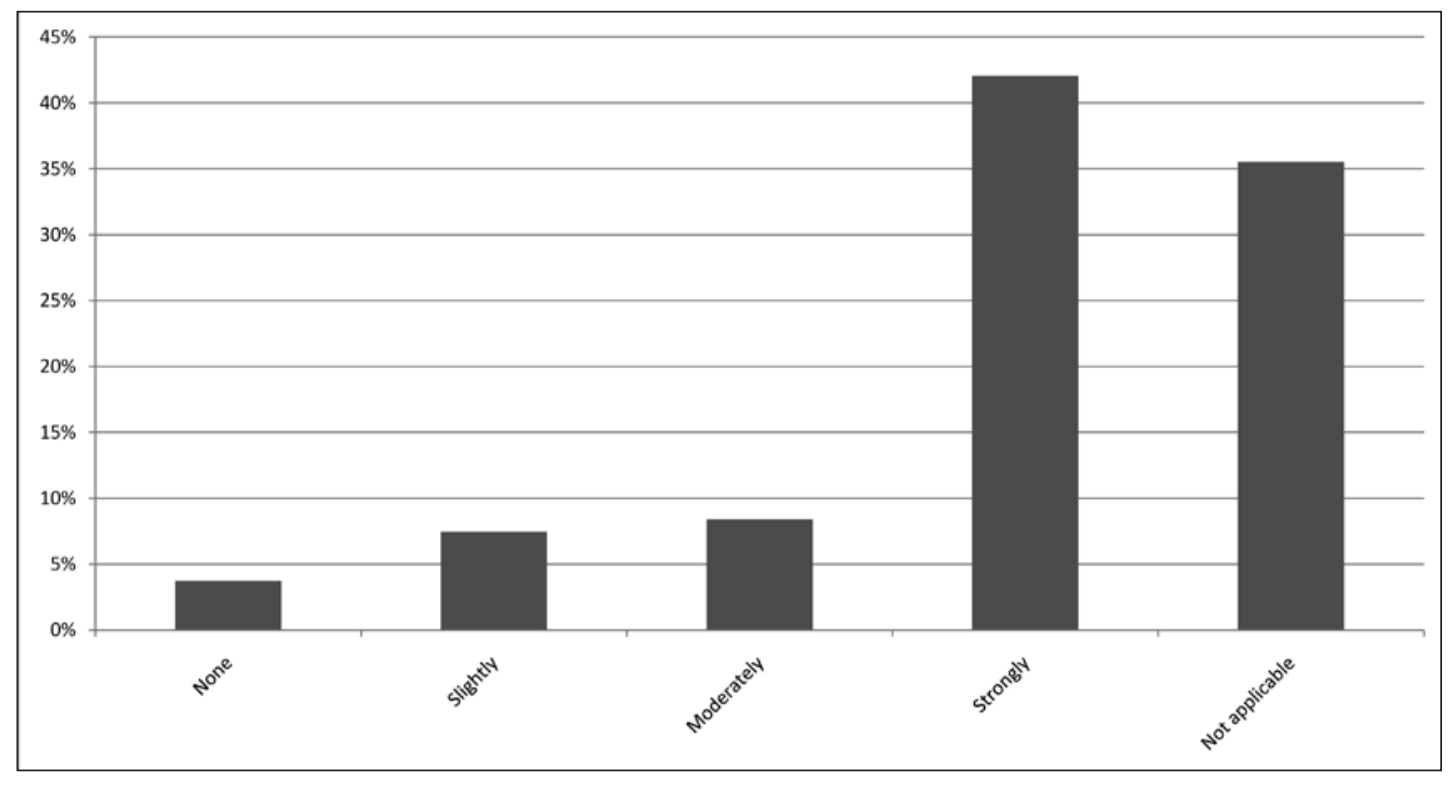

Figure 1. If you worked in a library prior to entering library school, how much do you think that influenced your decision to attend school?

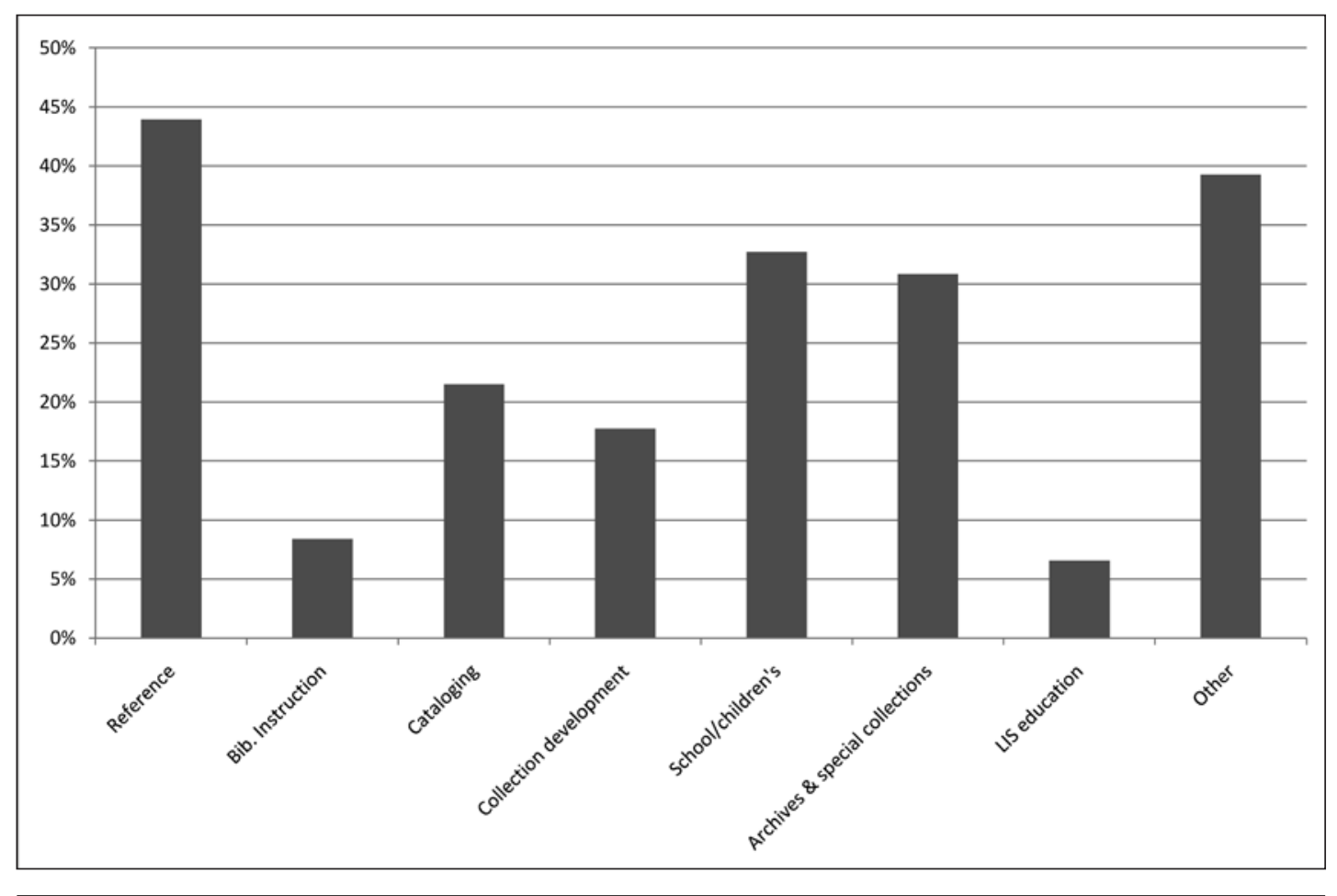

Figure 2. What specialty or track are you currently pursuing? (Check all that apply) 


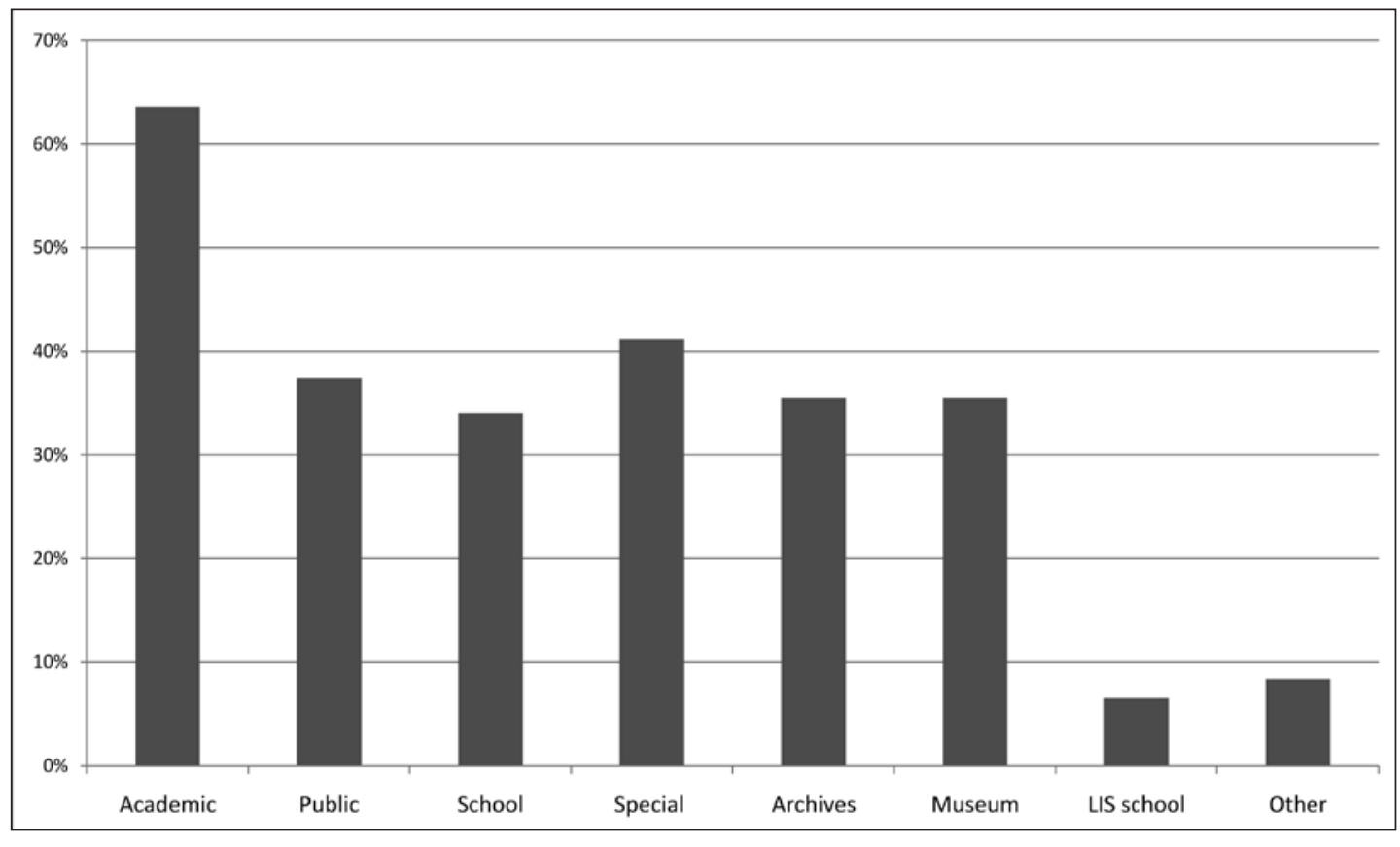

Figure 3. What type of library would you like to work in after you graduate? (Check all that apply)

did the 2004 respondents. Most of the 2004 respondents marked one of the traditional subfields while only a few checked "other." In contrast, 8 percent of the 2009 survey checked "other." The 2009 respondents listed a range of specialties under "other," including military, history of library, medical, art, music, legal, federal, digital, and metadata. This finding indicates both a surge of interest in special librarianship and the rise of new technology-based subfields (like metadata) that have grown outside the scope of the traditional subfields. On this same note, The Bowker Annual notes that the number of American LIS graduates finding jobs in nonlibrary settings has increased steadily, and many of our respondents may be aware of this trend and hoping to seize upon new opportunities for special librarians in industry, government, universities, and nonprofit organizations. ${ }^{18}$ The respondents' interest in so many specialized subfields once again reflects the variety of career backgrounds and interests in the LIS field.

In the question about types of library preferred (figure 3), 64 percent of students voted academic libraries as their most preferred type. Public libraries held at around 40 percent, roughly the same as 2004. Of the 2009 respondents, 36 percent expressed interest in archives and 36 percent in museums. Students with an interest in archives may also have an interest in museums and vice versa. The number of people leaning towards nontraditional library settings increased from 2004, with 41 percent checking special libraries in 2009 compared to 34 percent five years ago. One point to note is that many of those indicating an interest in specialized library work (like art or medical) in the previous question about subfields may hope to work in academic libraries as specialists and thus did not check special libraries in this question.

LIS students remain open to many subfields as they start their careers; greater numbers wrote in specialized subfields and libraries than in 2004. In addition, 76 percent of the 2009 respondents said they had not changed their minds about their preferred subfield since starting the LIS program, a number consistent with 2004 (74 percent). These findings suggest definite, specific preferences. However, only a little more than half of the 2009 students said they knew what subfield they wanted to pursue when starting their LIS studies, roughly the same as in 2004. More tellingly, as the percentages reveal, many respondents also checked multiple subfields or types of libraries when asked about their preferences. Thus most LIS students have open minds about specialty tracks as they embark on their careers, even though some pursue very specialized career goals.

\section{FACTORS SHAPING CAREER DECISIONS}

A fundamental question included in the 2004 survey and reiterated in the present one had to 


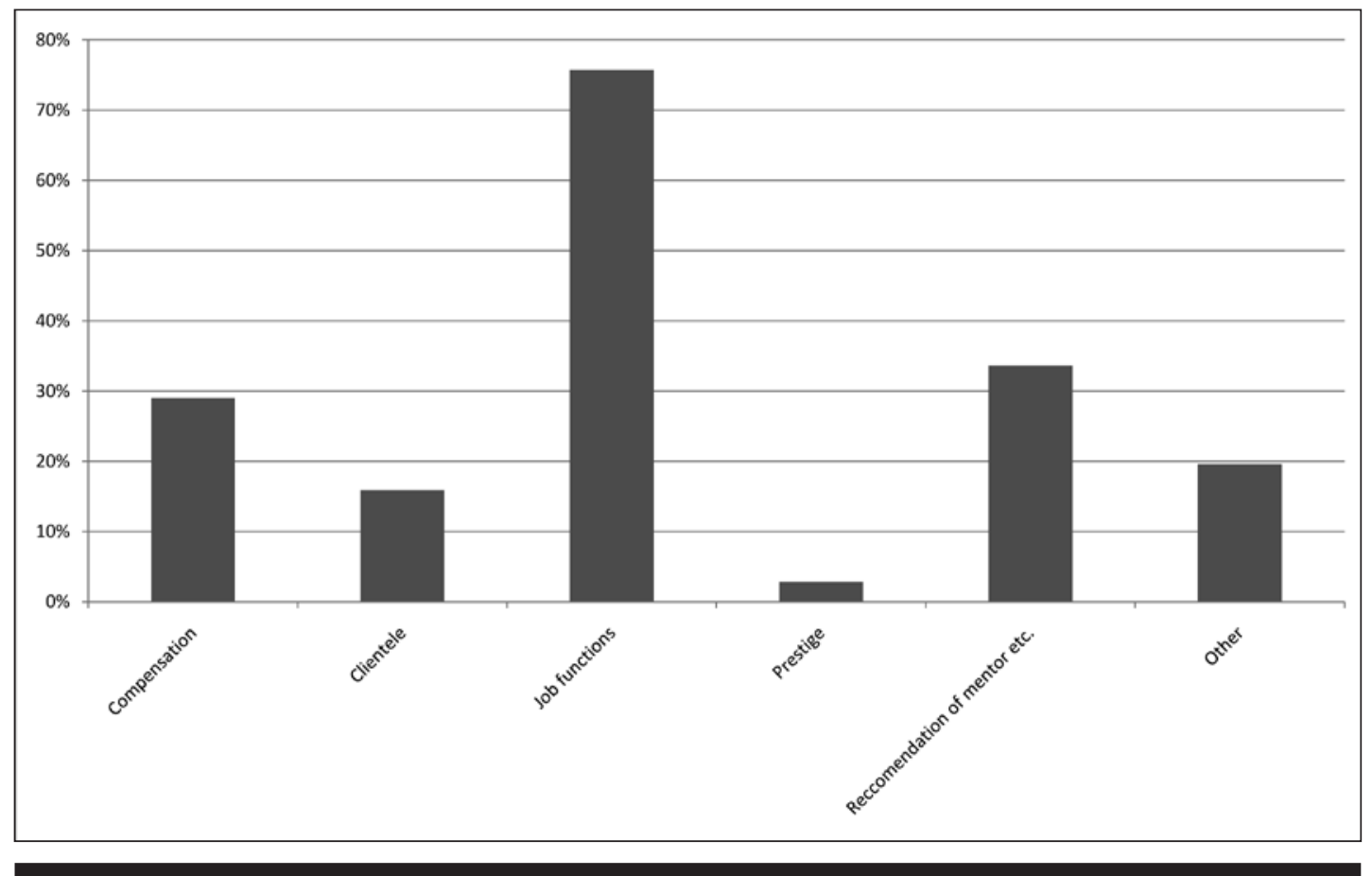

Figure 4. What factors affected your decision to enter the MLIS program? (Check all that apply)

do with career motivations (figure 4). We asked current LIS students to mark the factors that most affected their decision to pursue information science or a particular type of librarianship as a profession. The majority of the 2009 respondents had the same response as the 2004 respondents, with 76 percent checking "job functions" as the main factor, 34 percent marked "recommendation of a mentor, professor, coworker, or friend," and, as in the 2004 survey, less than 30 percent of students marked "compensation" as a motivating factor. The remaining factors had far less than a 30 percent response rate, but they should not necessarily be discounted as potential motivations for future LIS students. Students also wrote in "love of books" and a number of other responses, many of them related to job function, that were noted in the introduction to this article. This data indicates that the majority of LIS students are more concerned with the specific functions of librarianship than with the prestige, compensation, or other benefits that might influence a decision to pursue another, more high-profile career.

\section{CONFERENCE ATTENDANCE}

Most LIS students (73 percent) have attended or plan to attend a professional conference while still in school, a higher number than in 2004 (65 percent). While conference attendance often involves significant travel costs, SLIS students perceive an overriding value in participating. The high response rate could be attributed to the fact that UA SLIS also provides travel assistance funds, and some UA SLIS courses encourage or require conference attendance. Interestingly, distance students have attended or planned to attend conferences at a slightly higher rate (79 percent) than did onsite students (71 percent), perhaps because distance students taking courses remotely may view conferences as a way to help them connect more fully with the profession.

When asked if they plan to use job placement services at conferences, a little more than half answered affirmatively. This number has grown significantly from 2004, when only a third said they would use such services. Are conference planners marketing placement services more heavily than in the past? Or, more likely, has the economic downturn spurred more students into taking advantage of professional assistance with their job searches?

\section{JOB MARKET}

One of the most significant changes in the 2009 study when compared with the 2004 research is the alteration in how library and information studies students view the future job market. In the initial study, a majority of those surveyed (61 percent) viewed the future job market as "great" or "good." 


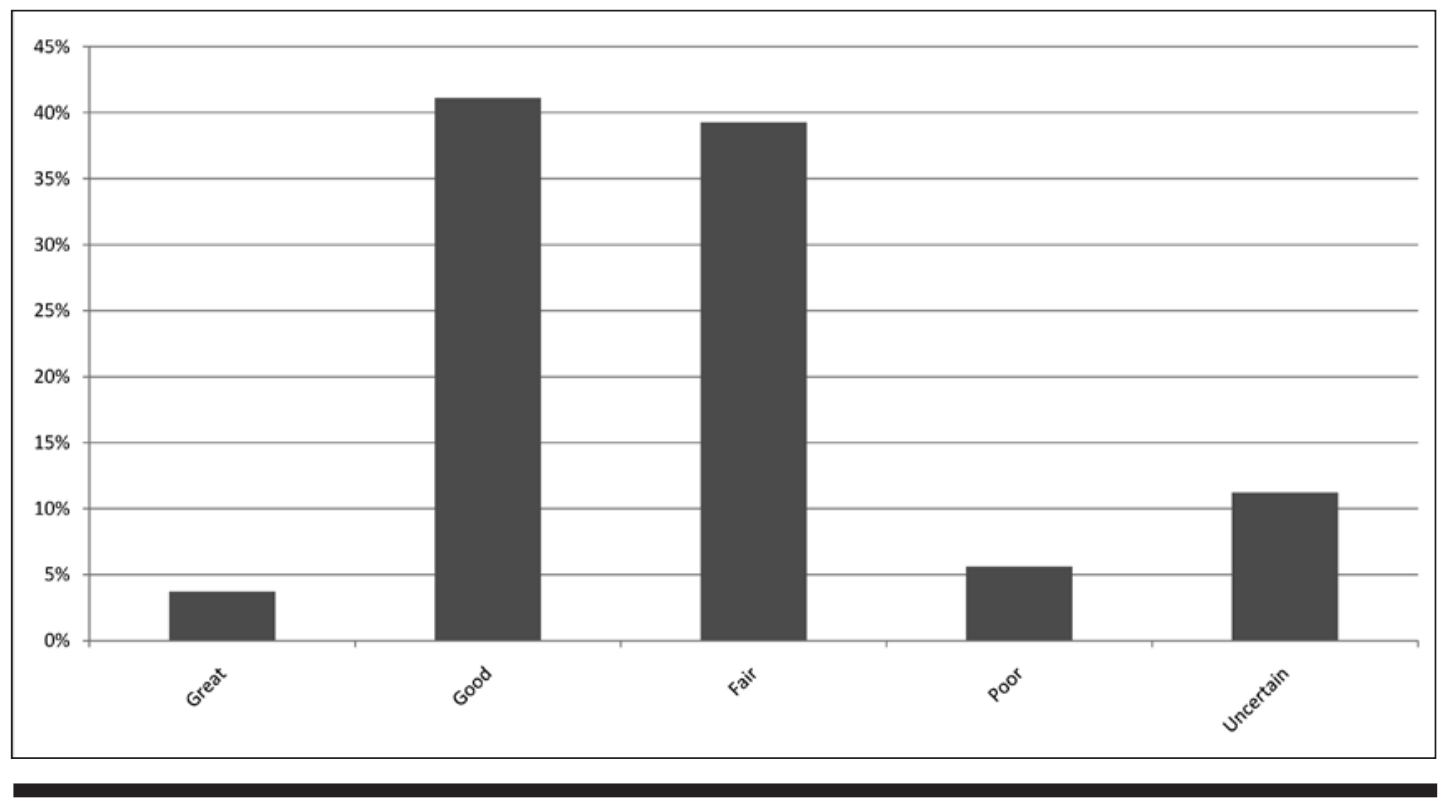

Figure 5. How do you think the job market, in general, looks for librarians and information specialists?

However, in our results (figure 5), we found that a mere 4 percent considered the job market "great," only 41 percent viewed the job market as "good," followed closely by 39 percent who viewed the job market as "fair." Only 6 percent considered the job market "poor" (no one considered it poor in 2004). We found this to be a significant change from the previous research, and the economic recession very likely explains this decline in expectations.

Interestingly, 50 percent of the 2009 students stated that attending library school had made them become more hopeful about the future of LIS. An overwhelmingly large number of students thought that they would be working in an LIS career in the next few years: 85 percent believed that their futures lay in the field, whereas less than 1 percent believed they would not be working in an LIS career in the next few years. A small percentage (11 percent) said they were uncertain about their futures in this field. Thus, while fears about the job market have noticeably increased, most LIS students anticipate finding jobs in the field and continuing to work in libraries over the long run.

\section{SALARIES}

We also wondered if the current economic malaise had depressed students' expectations about salary levels. Figure 6 shows that the largest number of students (25 percent) expected to make between $\$ 30,000$ and $\$ 34,999$ as starting librarians. This range also had the highest number of responses in 2004, although the percentage of students expecting such a salary had declined from 32 per- cent in 2004. About 43 percent of 2009 students anticipated making below $\$ 34,999$, while 48 percent expected to make higher. Surprisingly, this finding reflects higher expectations than in 2004 when 55 percent of students believed they would make below $\$ 34,999$ and 45 percent thought they would make higher. In addition, fourteen students in 2009 thought they would receive in excess of $\$ 45,000$, compared to only one student in 2004 . Economic concerns have not translated into lower salary expectations, in contrast to views on the job market. LIS students apparently believe that the number of jobs has declined somewhat, but there are jobs out there and they offer good salaries.

Library Journal reports that entry-level salaries have increased nationally over the past several years to an average of $\$ 42,361$ in $2007 .{ }^{19}$ LIS students' expectations have increased as well, perhaps because the students have enough contact with the field to know about the general rise in compensation. However, what will students' expectations (and actual salary levels) be in the next year or two when the recession's fallout might impose more budget cuts on libraries - and perhaps lower salaries?

Distance students had higher expectations about salary than did onsite students: 72 percent of distance students anticipated making in excess of $\$ 34,999$ compared to 59 percent of onsite students. One distance student checked a high salary range and wrote in a comment that may help explain this result, noting that "I'll have five years of library employment experience by the time I finish" the MLIS degree. A higher proportion of distance students may already be working in 


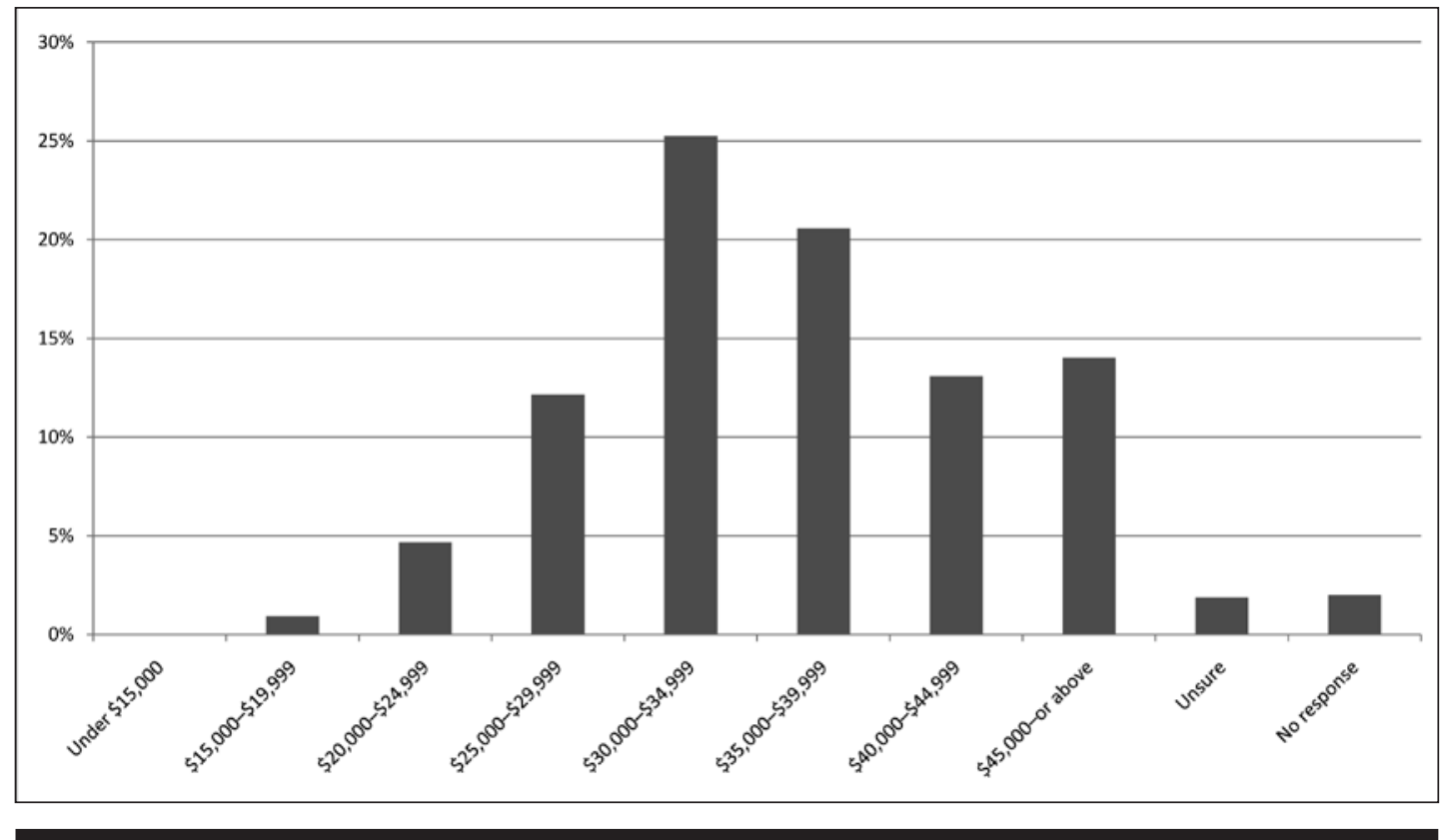

Figure 6. What kind of salary (excluding benefits) do you expect to make as a starting librarian?

libraries and garnering experience that will help them land higher paying jobs. Additionally, since many distance students live outside of Alabama, in places where the cost of living, and thus average salaries, may be higher, it stands to reason that these students expect to earn a higher salary.

As one of the authors keenly pointed out in 2004, those who analyze survey results about salaries should keep in mind two variables that may become mixed in respondents' thinking: students may expect to make within a certain range, but hope to make much more.

\section{GEOGRAPHIC PREFERENCES}

Career experts often emphasize geographic mobility as a key to finding a job in LIS, but most LIS students continue to have location preferences, as they did in 2004. As figure 7 reveals, 68 percent of respondents in 2009 marked that they want to work in "Alabama" or "Alabama or another southeastern state." Because our sample included many distance students, we assumed that many of them would have preferred to work outside Alabama because they reside elsewhere in the United States and take online courses. However, we realized that some of the distance students are Alabamians who reside in other parts of the state and find it preferable to take distance courses via a computer or at the remote site in Gadsden rather than commute or move to Tuscaloosa. These distance students, like their onsite colleagues, may prefer to remain in Alabama or the Southeast because of family and friends, familiarity with the area, or home ownership. Only 23 percent of all students said they would be willing to work "anywhere" when asked, meaning that the overwhelming majority of LIS students have some geographic preferences. If UA is a guide, it appears that library administrators-whether hiring new librarians from distance or onsite programs-will continue to have excellent luck recruiting graduates from library schools in their regions.

\section{LEARNING ABOUT SLIS}

Determining how students found out about UA's SLIS program is of particular importance to administrators and others involved in the recruitment of talented and intelligent individuals to their programs. Once this is decided, administrators can decide how best to attract students to their library schools. In response to the question "how did you first hear about the University of Alabama's School of Library and Information Studies?" 51 percent of respondents selected "word-of-mouth," 22 percent checked "SLIS website," and 17 percent selected "a directory or catalog of LIS programs." Distance students relied on word-of-mouth (36 percent) less than onsite students (59 percent). Overall, however, the majority of students learned about SLIS through unofficial means. SLIS students and alumni likely play a key role in promoting the school. For example, one student wrote that he discovered UA SLIS when they asked graduate students at a conference about LIS schools, and UA students "were universally proud and positive" about their program. These findings raise an important question: should LIS schools primarily 


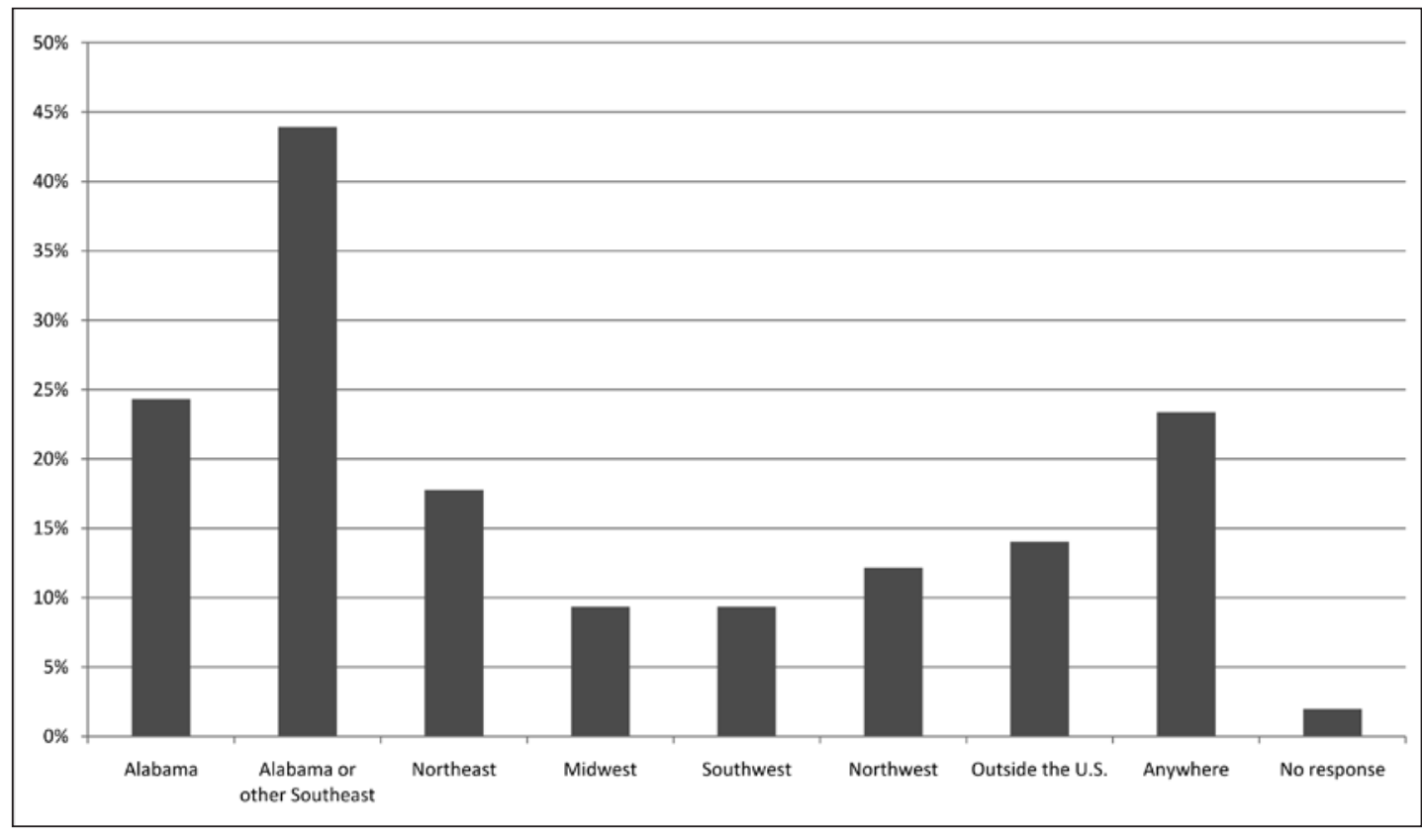

Figure 7. What geographic areas would you like to work in after you become a librarian? (Check all that apply)

use word-of-mouth to market themselves or focus on more formal ways to raise their visibility or a combination of both?

\section{TECHNOLOGY}

The 2009 survey included new questions dealing with the importance of technology within librarianship as well as questions measuring student proficiency with information technologies. We asked current LIS students to rank between one and ten how important it is to be able to use information technologies, one being not important at all and ten being extremely important. While there were a few dissenters, the majority of students (68 percent) ranked information technology a ten. We also asked students to rate how important they thought information technologies were to the profession prior to attending library school. The results came out much more scattered, with no single numeral gaining a majority: 24 percent ranked it a ten, 23 percent ranked it a seven, 16 percent ranked it a five, and approximately 15 percent ranked it at eight. The importance attributed to information technologies may be a result or correlate of attending library school. UA's SLIS program offers several courses specifically about technology, and most of the other courses stress technology in some way. Interestingly, the majority of students rated their own proficiencies in the "good" (50 percent) or "excellent" categories (22 percent), while only 25 percent selected "fair" and
2 percent selected "poor." Onsite students rated their skills as "good" or "excellent" 69 percent of the time while distance students rated their skills "good" or "excellent" 77 percent of the time.

The reason we included questions regarding information technologies and students' proficiency is that technologies are even more prevalent in 2009 than they were in 2004 . The results of the survey confirm this: the vast majority of current LIS students believe that information technologies have come to play an extremely important role in the profession. Additionally, it is no surprise that many students rate their own proficiencies as "good" or "excellent." Computers have been a vital part of American cultural and business life for more than twenty years, and many current LIS students have substantial experience with the day-to-day functions of particular information technologies.

\section{CONCLUSIONS}

The results of the updated survey have most prominently illustrated the diversity of SLIS students' educational and career backgrounds. For most of them, their love of library work motivated them to become librarians. Many worked in libraries before starting their degrees. Like their 2004 predecessors, they most prefer reference and academic libraries but not overwhelmingly so, as most are also open to many types of specialties. The number of students pursuing special librarianship or nontraditional 
types of library work has risen greatly since 2004. The 2009 cohort has more specific geographic preferences, as well as higher expectations about salaries, but lower expectations about the job market compared to 2004. Most students had heard about SLIS through word-of-mouth. We had expected major differences between distance and onsite students; however, the two groups proved remarkably similar in most ways. Some of the only differences were that distance students had higher expectations about salaries and were more likely to have heard about UA's SLIS through means other than word-ofmouth. Given the fact that many distance students live outside of Alabama, it is reasonable to assume that UA SLIS, as well as its reputation, is less well known; therefore the grapevine is a less effective means for advertising the program.

The survey has given insight into how to improve recruitment strategies. By understanding who library students are and why they are pursuing MLIS degrees, educators and reference librarians can better tailor their efforts. Reference librarians are well positioned to help with recruitment because they have so many opportunities to advertise LIS careers to the public: they can talk with patrons during reference interviews, mention LIS careers in their bibliographic instruction sessions, build Web links from their libraries' home pages to LIS recruitment pages, participate in career fairs, as well as create exhibits and bulletin boards. Often, their recruitment efforts are simply informal conversations that come up in the course of their job-many RUSQ readers have probably taken the time to talk with an inquisitive patron or acquaintance about the merits of an LIS career and gotten an interested response or perhaps even sold someone completely on a library career. Reference librarians may also have the opportunity to take part in formal campaigns on their campuses or in their communities. In addition to looking outside their libraries for new colleagues, reference librarians should remember that many potential recruits are already working as staff in their libraries. To support all of these different kinds of recruitment efforts, ALA has developed a wiki page, Recruitment Clearinghouse (http://wikis.ala.org/recruit/ index.php/Main_Page), dedicated to attracting individuals from a diverse array of groups to careers in librarianship, a great resource that reference librarians can tap into for brochures, posters, tips about specific populations, and other materials. ${ }^{20}$

The previous career survey article offered many practical ideas on recruitment. Based on our data, we would like to reiterate a few of those ideas, and offer some additional thoughts about how reference librarians can recruit new colleagues:

\section{Target Students of All Levels}

The results of our survey show that having a career in librarianship was not a goal for most students until after college. The library profession must target students earlier in their academic careers, while still in college or even high school. School librarians can guide student workers onto the library career path, as one librarian did at Colerain High School in Cincinnati, Ohio. In this case, a high school librarian was supervising a freshmen student who seemed to have great promise as a librarian, and after collaborating with her principal to create a for-credit library internship for the student, the student is now pursuing a career as a history librarian. ${ }^{21}$ By thinking creatively, reference librarians at academic libraries can get on board with teen recruitment. For example, Simmons College in Boston has created an internship program, Mass BLAST (Building Library Awareness and Staff for Tomorrow), specifically for local teens. The program teaches teens about all aspects of the library_including research skills and strategies designed to help students in college-and promotes librarianship as a potential career. ${ }^{22}$ ALA's job-related wiki offers links to flyers and posters that appeal to undergraduates and teens as well as examples of what other schools and colleges are doing to win students over to LIS. ${ }^{23}$

\section{Increase MLIS Programs'Visibility}

According to our data, most current students found out about UA's SLIS program through nonofficial means. As stated above, 51 percent of SLIS students heard about the program by wordof-mouth, while only 39 percent heard of it via official documents (of them, 22 percent used the SLIS website, and 17 percent consulted a directory or catalog of LIS programs). While recruitment via word-of-mouth is no less effective than other methods, reference librarians should try to step up efforts to disseminate formal materials, such as brochures and webpages, from specific MLIS programs. Reference librarians can join forces with an alma mater, or with LIS schools in their states, to find ways to distribute the schools' course offerings, entry requirements, and other information to interested patrons and library staff. Appropriately placed brochures and Web links may reach people that the grapevine cannot. Reference librarians can also bolster their internal recruitment efforts by drawing on these materials, perhaps by following up on a promising talk with a patron by handing them a brochure from a nearby library school or by e-mailing a link about an LIS school's distance program to interested library staff members who 
would need to continue working while taking courses.

\section{Exude Enthusiasm for Your Profession}

An overwhelming majority of current SLIS students ( 76 percent) indicated that job function was the primary motivator in their decision to pursue librarianship as a career. Additionally, 42 percent replied that previous library experience strongly influenced that decision. From these statistics, it is possible to infer that library students and library employees either anticipate or report high levels of job satisfaction. Thus reference librarians who enjoy their jobs should express their satisfaction to others in conversations that come up with patrons at the reference desk or even mention their love of the field in bibliographic instruction sessions, perhaps when introducing themselves. Enthusiasm can be catching! For reference librarians, the thrill of the hunt for an elusive answer to a reference question, the gleam in someone's eye when she finds an answer, opportunities to teach one-on-one and in groups, the chance to learn something new every day, and the service orientation of the job are all satisfying aspects of the reference function that they can share with patrons.

\section{Stress the Fact that Librarians Earn Competitive Salaries}

Not only do librarians have a high level of job satisfaction, they also make good salaries. According to the 2008-9 edition of the Occupational Outlook Handbook, the median annual earnings of librarians in 2006 was $\$ 49,060 .{ }^{24}$ According to the Statistical Abstract of the United States, the 2006 per capita income for all jobs in the United States was $\$ 26,352 .{ }^{25}$ The Occupational Outlook Handbook notes that the 2006 median salary range for teachers was $\$ 43,580$ to $\$ 48,690 .{ }^{26}$ Librarians thus earn salaries that are both higher than most jobs in the United States and commensurate with related fields. Our survey participants were aware of this fact; 14 percent of our participants expect to earn more than $\$ 45,000$ a year, and 34 percent expect to earn between $\$ 35,000$ and $\$ 45,000$ a year. Reference librarians must further increase this awareness among potential recruits by quoting statistics like these.

\section{Emphasize the Broad Appeal of Librarianship}

When asked what areas they were pursuing, survey participants listed a wide range of tracks. Furthermore, there was a broad selection of the type of libraries students would like to work in after graduation and even some nonlibrary institutions such as museums. Before starting library school, many students were unaware of the diversity of career options within the profession: 46 percent of students did not know what particular track they wanted to pursue, while 22 percent have changed their intended path of study after beginning library school. It seems that the broad appeal of librarianship changed the minds of these students because library school made them aware of other potential career choices. By emphasizing the flexibility of the MLIS-one can take many paths within the career and work in many different types of libraries-the profession can attract a more diverse group of potential students. For example, librarians participating in school, college, or community career fairs could showcase the many options in the field, remembering that each specialty track will appeal to a different group.

Additionally, reference librarians can explain to people considering a career change that they can build on their subject knowledge (such as medicine, law, business) to become special librarians in that field. Librarians can point out to students graduating from programs with a dearth of jobs, such as history, that they can earn an MLIS degree and become a specialist for their subject, thus allowing them to use their original degree while also working as a librarian. Many of our respondents indicated an interest in these kinds of subjectspecialized positions. One of the most unique selling points of our field is that people can combine their prior knowledge in and love of any subject area with a new career in librarianship.

\section{Stress Books and Technology}

"Love of books" continues to attract people to the field, but the opportunity to work with information technology does as well. We know this because most students chose LIS for its job functions, and most of them were also aware that technology is integral to these job functions. Taken together, these two findings suggest that LIS students look forward to using information technologies as part of their jobs. Therefore, when trying to create interest in the LIS field, reference librarians should stress not only books but also the chance to work with databases, virtual reference services, new types of productivity software, Web 2.0 applications for libraries, and other technologies.

\section{Unseat the Stereotype!}

The popular cultural image of "The Librarian" is 
that of an older, ultraconservative woman shushing noisy patrons in a dusty library. This stereotype, however, is far from reality: the majority of respondents to our questionnaire were under thirty years of age, and 25 percent were male. Additionally, librarians hold, at least professionally, progressive ideals: librarians are anticensorship, firm believers in an individual's right to privacy, and staunchly opposed to any force that seeks to violate those rights (most recently the USA PATRIOT Act). Librarians also are egalitarians who believe that free access to information should be provided to all.

Librarians come from diverse educational and occupational backgrounds. Current SLIS students have degrees in, among other fields, English, history, art, education, music, psychology, theater, and biology. They have worked as teachers, lawyers, and homemakers. Also participating in this study were a professional pianist, an archaeologist, a mineralogist, and a journalist. Recruitment programs should convey that librarianship is an exciting career and one that is as diverse and interesting as the people it attracts.

As with most fields, one of the most critical tasks for librarians is discovering, mentoring, and supporting new colleagues. Former RUSQ editors and others have done much to convince RUSA of this basic occupational responsibility. The LIS profession must ensure a steady supply of talented and diverse professionals to replace those who will retire and to provide the leadership that libraries need in these changing times. Surveys of MLIS students can inform reference librarians carrying out this mission, and we hope our study inspires other researchers to conduct similar studies. By continuing to take an interest in MLIS students and solicit their ideas about the field, reference librarians and others library professionals focused on finding new colleagues can gain insights to help them coordinate the profession's formal recruitment campaigns and guide them in those informal opportunities to talk with people about the rewards of a library career. Such outreach by reference librarians can give the entire LIS field a brighter future.

\section{References}

1. Allyson Ard et al., "Why Library and Information Science?" Reference \& User Services Quarterly 45, no. 3 (Spring 2006): 236-48.

2. John Berry, "Addressing the Recruitment and Diversity Crisis," American Libraries 33, no. 2 (Feb. 2002): 7.

3. American Library Association, "Recruitment Assembly," www.ala.org/ala/aboutala/offices/hrdr/alarecruit mentassembly/alarecruitmentassembly.cfm (accessed May 20, 2009).

4. Occupational Outlook Handbook, 2008-9 ed. (Washington, D.C.: U.S. Department of Labor, 2008).
5. Stephanie Maatta, "Placements \& Salary Survey 2008: Jobs and Pay Both Up," Library Journal (Oct. 15, 2008), www.libraryjournal.com/article/ca6602855. html?q=job+salaries (accessed May 20, 2009).

6. Liz Wolgemuth, "The 30 Best Careers for 2009," U.S. News \& World Report (Dec. 11, 2008), www.usnews .com/articles/business/best-careers/2008/12/11/the -30-best-careers-for-2009.html (accessed May 20, 2009).

7. Connie Van Fleet and Danny P. Wallace, "O Librarian, Where Art Thou?" Reference \& User Services Quarterly 41, no. 3 (Spring 2002): 215-17.

8. Donna M. Shannon, "School Librarianship: Career Choice and Recruitment," Journal of Education for Library \& Information Science 49, no. 3 (Summer 2008): 210-29.

9. Lorraine J. Pellack, "Uncle Albert Needs You!" Science E Technology Libraries 27, no. 1/2 (2006): 55-70.

10. Linda C. Smith, "New Models of Recruitment and (Continuing) Education for Sci-Tech Librarianship," Science \& Technology Libraries 27, no. 1/2 (2006): 173-84.

11. Kyung-Sun Kim and Sei-Ching Joanna Sin, "Recruiting and Retaining Students of Color in LIS Programs: Perspectives of Library and Information Professionals," Journal of Education for Library \& Information Science 47, no. 2 (Spring 2006): 81-95.

12. Todd M. Hines and Amia L. Baker, "The Career Choices of Business Librarians: A Survey and Discussion," Journal of Business E Finance Librarianship 13, no. 3 (2008): 391-404.

13. A. O. Issa and K. I. N. Nwalo, "Factors Affecting the Career Choice of Undergraduates in Nigerian Library and Information Science Schools," African Journal of Library, Archives \& Information Science 18, no. 1 (Apr. 2008): 23-31.

14. Barbara Dewey and Jillian Keally, "Recruiting for Diversity: Strategies for Twenty-First Century Research Librarianship," Library Hi Tech 26, no. 4 (2008): 622-29.

15. Workforce Issues in Library \& Information Science, www.wilis.unc.edu (accessed June 6, 2009).

16. Amy Chapman et al., "The GSLIS Future of the Profession Survey: Report," www.gslis.utexas.edu/ wyllys/ IRLISMaterials/surveyp9/FutureOfProfession01.pdf (accessed May 19, 2009).

17. Kathleen de la Pena McCook and William E. Moen, "Information Services Recruitment: The Challenge of Opportunity," RQ 29 (Summer 1990): 562-66.

18. Stephanie Maata, "Placements and Salaries: What's an MLIS Worth?" in The Bowker Annual, 53rd ed. (New York: R. R. Bowker, 2008): 407.

19. Maatta, "Placements and Salary Survey 2008."

20. American Library Association, "ALA Recruitment Clearinghouse," http://wikis.ala.org/recruit/index .php/Main_Page (accessed May 21, 2009).

21. Kathy Seaver, "From Helpful Teen to History Librarian: A Recruitment Story," Young Adult Library Services 7, no. 1 (Fall 2008): 24-25.

22. Simmons College, "Mass BLAST," www.simmons.edu/ massblast (accessed May 21, 2009).

23. American Library Association, "ALA Recruitment Clearinghouse."

24. Occupational Outlook Handbook.

25. Statistical Abstract of the United States, 128th ed (Washington, D.C.: U.S. Census Bureau, 2008): 449.

26. Occupational Outlook Handbook. 